\title{
Physicians' Knowledge, Opinions and Perceived Barriers to Hepatitis C Care at Ain Shams University Hospital
}

\author{
Maha M. Wahdan ${ }^{1 *}$, Hebat-Allah M.S. Gabal ${ }^{1}$, Mouaz M. Zaky ${ }^{2}$, Yasser A. Adam ${ }^{2}$, Mohamed M. \\ Abd El-Fattah ${ }^{2}$ \\ ${ }^{1}$ Department of Community, Environmental and Occupational Medicine, Faculty of Medicine, Ain Shams University. \\ ${ }^{2}$ Internship, Faculty of Medicine, Ain Shams University
}

\begin{abstract}
:
Background: Hepatitis $\mathrm{C}$ virus has global burden, but it is a potentially curable disease, with sustained virologic response among the majority of treated patients. In recent years, new treatments for hepatitis $C$ have been approved and represent a major advancement in treatment.

Objectives: This study was conducted to assess knowledge, opinions and perceived barriers to hepatitis c direct-Acting Antivirals (DAAs) based regimen among a sample of hepatitis $\mathrm{C}$ virus (HCV) treatment providers. Methods: A Cross-sectional study on HCV treatment providers at ElDemerdash, Ain Shams University Hospital was conducted. A total of 69 physicians responded to self-administered questionnaire about their knowledge, opinions on the services provided and perception towards treatment barriers.

Results: Most of physicians' opinions agreed with the current state of HCV care as exist of guidelines, patients have adequate access to HCV treatment providers; but they disagreed about that the general public is aware of $\mathrm{HCV}$ and know that it is a curable disease. Most of physicians $(81 \%)$ had high Knowledge level of HCV treatment principles. The most perceived barriers to care were Payer-related barriers followed by government-related barriers and patient-related barriers.

Conclusion: The study highlights the most perceived barriers that may impede the prompt and appropriate treatment of hepatitis $\mathrm{C}$ virus infection reported by treating physicians. Therefore, it is important to engage $\mathrm{HCV}$ treatment providers in Educational programs that can help to modify their knowledge about HCV treatment and related services, and their communication and practice in guiding patients in their treatment course.
\end{abstract}

Keywords: Direct-Acting Anti-virals, HCV treatment, Healthcare provider knowledge, Opinions, Perceived barriers.

\section{Introduction:}

Hepatitis $\mathrm{C}$ virus (HCV) infection is an important global health issue. It is estimated that a significant part of the world population is chronically infected with the virus where 130-150 million people live with chronic HCV infection, and about 350,000-500,000 $\mathrm{HCV}$-related deaths occur each year. Acute $\mathrm{HCV}$ progresses to chronic infection in 55$85 \%$ of cases; $15-30 \%$ of these will develop complications of chronic liver disease, such as liver cirrhosis, and 1-5\% will develop liver cancer. $^{2,3,4}$ Hepatitis C virus (HCV) has high genetic diversity with regional variations in genotype prevalence which gives challenge in development of vaccines and pan-genotypic treatments. ${ }^{5}$ The HCV is a potentially curable disease, developments in hepatitis $\mathrm{C}$ treatment gained speed in the last decade. Several new treatment options are emerging and are available to a large part of the affected population with promise of a sustained

*Corresponding author: E-mail: drmaha_wahdan@med.asu.edu.eg 
virologic response (SVR) among the majority of treated patients. ${ }^{6}$

However, in developing countries, there is limited access to hepatitis treatment due to defects in their health systems and insurance coverage, absence of local and national political support in fighting the infection, lack of trained personnel, and lack of diagnostics. ${ }^{7}$ In Egypt, HCV is a major public health problem and according to Egypt Health Issues Survey (EHIS) (2015) results, the prevalence of $\mathrm{HCV}$ antibody in the 15-59 year age groups was found to be $10.0 \%$ while $\mathrm{HCV}$ RNA was $7.0 \%$ and approximately, 3.7 million persons have chronic $\mathrm{HCV}$ infection. $^{2}$

Therefore, an estimated 29\% reduction in $\mathrm{HCV}$ RNA prevalence has been seen since 2008, which attributed to prevention efforts and the ageing of the group infected 40-50 years ago during the mass schistosomiasis treatment campaigns. ${ }^{17}$ Prevention efforts for combating $\mathrm{HCV}$ problem were held by the Ministry of Health and Population (MOHP) through establishing the National Committee for the Control of Viral Hepatitis (NCCVH) in 2006. By 2008, this committee had developed a National Control Strategy for Viral Hepatitis, and developed an action plan by 2014 which called for effective surveillance, enhancements in prevention, and expanded access to care and treatment for those with chronic infection. ${ }^{8}$

Recently, MOHP had introduced new, highly-effective medication, once-daily, oral interferon-free treatments with minimal adverse effects to treat $\mathrm{HCV}$ infection at an affordable price. Introduction of direct-acting antivirals (DAAs) leads to dramatically improved Hepatitis $\mathrm{C}$ treatment which cures up to $95 \%$ of patients. ${ }^{9-11}$ According to the National Institutes of Health Consensus statement on $\mathrm{HCV}$ infection, successful $\mathrm{HCV}$ treatment requires staying on the prescribed dose of medications for the prescribed period of time. ${ }^{9}$ But multiple factors serve as barriers to the delivery of antiviral therapy arises to interfere with treatment course as patients may have fear of treatment-related side effects, financial constraints, and social stigmatization; also, physicians may fail to refer patients for subspecialty evaluation or may emphasis on purported contraindications as psychiatric disease, substance use, or medical comorbidities. Also, limitations in funding, medical coverage, and office staffing may prevent treatment. ${ }^{6}$

Therefore, the aim of this study was to assess physicians' knowledge about directacting antivirals (DAAs) based regimen as 
HCV treatment, and to identify their opinions and perceived barriers to $\mathrm{HCV}$ care at Ain Shams University Hospitals.

\section{Methods:}

Study design and setting: A cross-sectional study was carried out between August 2017 and January 2018. The study took place at $\mathrm{HCV}$ treatment clinic in El-Demerdash, Ain Shams University hospitals.

Study participants: The study population composed of 69 physicians working in internal medicine and tropical departments at El-Demerdash, Ain Shams University hospitals who participate in hepatitis $\mathrm{C}$ virus treatment. Physicians were considered eligible for the study if they treated a minimum of 10 $\mathrm{HCV}$ patients.

Sampling method: Systematic random sampling involved randomly selecting two days per week, and this random selection repeated every week for two months period with exclusion of weekends then took available physicians working at $\mathrm{HCV}$ treatment clinic at selected days.

Sample size: A sample size of 65 produces a two-sided $95 \%$ confidence interval with a distance from the mean to the limits that is equal to 1 when the estimated standard deviation is 4.0 according to McGowan et.al, 2013. ${ }^{7}$

Data collection tool: A modified structured anonymous self-administered questionnaire was used. It was adapted from the validated structured questionnaire by the International Conquer C Coalition (IC3), an organization of hepatitis $\mathrm{C}$ experts formed with the goal of optimizing global HCV care. ${ }^{7}$

\section{The questionnaire consisted of four} sections:

- Section 1: Physicians' Characteristics: age, sex, medical specialty and job category for each physician were documented.

- Section 2: Physicians' Opinions Regarding HCV Care (8 questions):

Physicians' Opinions regarding the current state of HCV care were assessed according to level of agreement with the statements about: national and international treatment guidelines recognition and availability; consistent among stakeholders including professional societies, payers, and government; healthcare providers have knowledge of screening and treatment guidelines; the general public is aware of $\mathrm{HCV}$, curability and understand the consequences of $\mathrm{HCV}$ if it is not treated; patients have adequate access to $\mathrm{HCV}$ providers in their community. 
- Section 3: Knowledge about HCV treatment (26 questions):

Physician knowledge was assessed according to level of agreement with the following points: including statements about drug used and its regimen, contraindication, side-effects and follow up. For example, the addition of ribavirin to peg-interferon improves the likelihood of SVR; maintaining an optimal dose of ribavirin with interferon is necessary to achieve an SVR; different viral genotypes require different treatment durations; treatment should be discontinued for patients who fail to achieve a 2-log decrease in $\mathrm{HCV}$ RNA by treatment week 12; the level of HCV RNA has no correlation with the severity of liver disease; maintenance therapy should be prescribed for treatment non-responders.

Each response for knowledge was rated with 0 representing "wrong answer" 5, representing "don't know" and 10 representing "right answer". Then composite score was calculated for each physician with maximum total score of 260 .

- Section 4: Barriers to Care (31 questions): Assessment of 31 potential perceived barriers categorized by patient, provider, government, and payer related categories. Each response was a 10-point Likert scale, with 0 representing "not a barrier to treatment," 5 representing "somewhat of a barrier to treatment," and 10 representing "large barrier to treatment."

A composite score for each dimension of barriers was calculated for each physician. Therefore, Total score of patient related barriers was 120 , Total score of government related barriers was 30, Total score of provider related barriers was 70 and Total score of payer related barriers was 90 .

\section{Data management and analysis:}

Data were managed with Statistical Package for Social Sciences (SPSS) version 20 for windows. Data were checked for accuracy of data entry and missing values. Descriptive statistics as frequency, percentage for categorical data were calculated. Composite scores for knowledge section and different barriers dimensions were created and the mean and standard of the scores was calculated.

\section{Ethical consideration:}

Administrative approval from Ain Shams University hospitals was obtained. Researchers explained the purpose of the study and informed the participants about their rights, assuring them that the collected data will not be used for any purpose other than for the present study and that the data will be handled anonymously and Informed 
consents were taken from physicians before their participation in the study.

\section{Results:}

Description of study participants: Among 69 studied physicians, most respondents were females $(60 \%)$ and most of them where assistant lecturer $40(61.5 \%)$, while, residents contributed by $18(27.7 \%)$ and lecturer 7 $(10.8 \%)$.

Physicians' opinions about HCV care: The majority of physicians had positive opinions about the current state of $\mathrm{HCV}$ care in the country as shown in Table-1.

Physicians' knowledge about HCV treatment: The majority of physicians had correct answers about statements concerned with treatment dose, duration, contraindication and adverse events. However, they had low knowledge about dose adjustment and drug combinations as demonstrated in Table-2 and Table-3. The mean of knowledge total score was $(153.5 \pm 31.1)$ with the majority of Physicians (81\%) had high Knowledge level about HCV treatment principles.

Physicians' perceived barriers: The most perceived patient-related barriers were cost of treatment and lab investigation $(85.1 \%)$. The most perceived government-related barriers were lack of treatment promotion and insufficient funding $(58.8 \%$ and $48.5 \%$ respectively). The most perceived provider related barrier was lack of referral to $\mathrm{HCV}$ providers by other physicians $(47.0 \%)$. The most perceived Payer-related barriers were insurer does not cover serum marker for fibrosis and insurance plan will not cover RNA /genotyping $\quad(84.8 \%$ and $75.7 \%$ respectively).

Payer related barriers was one of the most important perceived barrier by $(87.9 \%)$ of physicians, then Government related barriers where $(66.2 \%)$ of physicians had high score, then Patient related barriers with $(61.9 \%)$ of physicians had high score, and the most least barrier was provider related barriers where only $(23.1 \%)$ of physicians had high score as shown in Table- 4 and Table-5.

Correlation between knowledge score and scores of different dimensions of barriers: It is evident there is a statistically significant correlation between knowledge score and scores of perceived patients' and providers' related barriers ( $r=-0.396 \& .338$ respectively) as found in Table-6.

\section{Discussion:}

The current study gave an a clear view as regards physicians' knowledge about hepatitis c treatment and the care provided and the 
perceived barriers to get the care from physicians' view in Egypt.

\section{Physicians' Opinions regarding hepatitis c}

Care: The majority of Physicians had positive opinions and agreement about the current state of $\mathrm{HCV}$ care in the country as "national treatment guidelines exists $(79.1 \%)$, adequate physicians' knowledge (69.1\%)" where the findings of guidelines were similar to those found in McGowan et al., 2013 study results in European countries $(71 \%-83 \%)$.

They were contradicted with physicians' opinions in North America, Latin America, and Middle East/Africa as only (36\%-38\%) of physicians agreed. In contrary of our study, McGowan et al., 2013, found low agreement level about "healthcare providers had adequate knowledge" $(20 \%-54 \%)$ in comparison to current situation $(69.1 \%)$; but, it was similar to that found in study conducted on primary healthcare physicians in Baltimore. ${ }^{6,15}$

On other hand, minority of physicians in current study agreed about "the general public is aware of HCV" (45.6\%), "most patients are aware that HCV is curable" (30.4\%), and "Patients understand the consequences of HCV if it is not treated" (26.9\%); and these findings agreed with McGowan et al., 2013 study about the patients related statement as awareness about $\mathrm{HCV}$ and its curability and the consequences of no treatment. In this respect, it is necessary for more promotion and health awareness campaigns for increase the community knowledge about $\mathrm{HCV}$ and its treatment. $^{7}$

\section{Physicians' Knowledge about hepatitis c} treatment: The mean knowledge score in the present study was $153.5 \pm 31.1$ with range (95-210) with majority of them having high scores $(81 \%)$ and this knowledge of HCV was likewise adequate among drug-treatment providers and this finding was similar to physicians results in Western Europe who correctly answer the most knowledge questions, but, those in Middle East and African countries correctly answering the fewest.

These results reflect that knowledge of $\mathrm{HCV}$ treatment principles varied by region as found in McGowan et al., 2013 study. ${ }^{7}$ In our study we found that there was high knowledge about HCV treatment dose, duration, contraindication and adverse events among physicians; but, they had low knowledge about dose adjustment and drug combination. This finding was similar to those reported by Falade-Nwulia et.al. 2016; and against other 
study conducted in China where there was poor physicians knowledge. ${ }^{14,15}$ In this respect, it is necessary for more educational sessions about the new treatment.

Perceived Barriers to Care: The current study results revealed that Payer related barriers was one of the most important perceived barrier including insurer does not cover serum marker for fibrosis and insurance plan will not cover RNA /genotyping which stress on the fact that patient will bear the cost of these procedures(out of pocket expenditure), then Government related barriers which include lack of treatment promotion and insufficient funding, then Patient related barriers which include cost of treatment and lab investigation, need for liver biopsy, inaccessibility of experienced providers and fear of side effects.

In McGowan et al., 2013 study, the different barriers across regions were assessed; and the results revealed that Payerrelated barriers were most prominent in Latin American and Middle East/Africa and included lack of coverage leading to out-ofpocket expense and excessive paperwork requirements ${ }^{7}$ as found in the current study.

But, patient-related barriers were viewed as most significant globally and this is against what found in the current study. Also, this was in contradiction with Evon et.al and Parkes et.al. where in surveys concluded that physicians in the United States and United Kingdom addressed that those patient level factors were the greatest obstacles to treatment $_{\text {principles. }}{ }^{12,13}$ Other previous studies agreed that barriers come from both individuals and the entire system. Therefore, $\mathrm{HCV}$ intervention should be a "combination intervention," that is, it should involve all possible barriers dimensions. ${ }^{14,16}$

Knowledge score was found to be statistically significant correlated with patients' and providers' barriers where it was found that physicians who scored lower on the knowledge assessment tended to perceive greater patients' barriers; therefore fewer patients would miss the treatment as a result of incorrectly perceived barriers. While Physicians with higher knowledge showed higher providers' barriers as they know what to do but they had barriers in providing care due to defect in supports and facilities. These perceived barriers may be overcome through improved education and improved the support to facilities provide $\mathrm{HCV}$ treatment and these results were similar to other findings in McGowan et al., 2013 study. ${ }^{(9)}$ 


\section{Study limitation:}

The current study was conducted in one hospital in Cairo, Egypt, thus physicians who completed the survey may not reflect the knowledge and opinions of all physicians in Egypt. Therefore, a better study design could have been adopted using sample of physicians from different types of hospitals in different governorates. Limited number of physicians' working in $\mathrm{HCV}$ treatment clinic who are eligible for participating in the study. There may be other barriers or facilities that prevent or enhance the HCV service that we did not examine in the current study. Future work will be conducted to clarify these issues especially from patients' perspective.

\section{Conclusion:}

The present study indicated that the majority of Physicians had positive opinions about the current state of HCV care in the country. Less than half of all surveyed physicians believed that the general public is aware about $\mathrm{HCV}$ and that it is a curable disease. Most of physicians had high Knowledge level about $\mathrm{HCV}$ treatment principles. The most perceived barriers to care cited were Payerrelated barriers mainly, then governmentrelated barriers then patient-related barriers and lastly provider related barriers.
It is recommended that improving provider knowledge and practice about how to guide patients to the correct path to get effective treatment, and ways to get low price treatment are necessary for progress in the fight against $\mathrm{HCV}$ infection through physician training. Patients' counseling and mass media awareness programs are important for improving patient awareness about treatment and its consequences.

Conflict of interests: There is no known conflict of interest associated with this publication.

Funding: There has been no financial support for this work that could have influenced its outcome.

Acknowledgment: The authors would like to express great appreciation to physicians in ElDemerdash, Ain Shams University Hospital who generously shared their time and participated in the current study.

\section{References:}

1. Perz J, Armstrong G, Farrington L et al. The contributions of hepatitis B virus and hepatitis $\mathrm{C}$ virus infections to cirrhosis and primary liver cancer worldwide. J Hepatol, 2006; 45(4): 529538. 
2. Ministry of Health and Population [Egypt], El-Zanaty and Associates [Egypt], and ICF International. Egypt Health Issues Survey 2015. Cairo, Egypt and Rockville, Maryland, USA: Ministry of Health and Population, ICF International; 2015. Available at: https://dhsprogram.com/pubs/pdf/FR313/ FR313.pdf. (Accessed 20 May 2018).

3. Cooke $\mathrm{G}$, Lemoine $\mathrm{M}$, Thursz $\mathrm{M}$ et al. Viral hepatitis and the Global Burden of Disease: a need to regroup. J Viral Hepat 2013; 20:600-601.

4. WHO. Hepatitis C fact sheet. WHO/164, Revised April 2014, Geneva. World Health Organization. Available at: http://www.who.int/mediacentre/factshee ts/fs164/en/. (Accessed 26 April 2018).

5. Messina J, Humphreys I, Flaxman A et al. Global distribution and prevalence of hepatitis $\mathrm{C}$ virus genotypes. Hepatology. 2015; Jan, 61(1): 77-87. Available at: http://www.ncbi.nlm.nih.gov/pmc/article s/PMC4303918/. (Accessed 20 May 2018).
6. Fried M, Shiffman M, Reddy K et al. Peginterferon alfa-2a plus ribavirin for chronic hepatitis $\mathrm{C}$ virus infection. $\mathrm{N}$ Engl J Med. 2002; 347(13):975-82. [PubMed: 12324553].

7. McGowan C, Monis A, Bacon B et al. A global view of hepatitis C: physician knowledge, opinions, and perceived barriers to care. Hepatology. 2013; 57(4):1325-1332. Available at: https://www.ncbi.nlm.nih.gov/pmc/articl es/PMC3683983/. (Accessed 22 June 2018).

8. Gomaa A, Allam N, Elsharkway A et al. Hepatitis C infection in Egypt: prevalence, impact and management strategies. Hepat Med. 2017; 9: 17-25. Available from: https://www.ncbi.nlm.nih.gov/pmc/articl es/PMC5439968/. (Accessed 22 June 2018).

9. Egyptian Ministry of Health and Population. Plan of action for the prevention, care \& treatment of viral hepatitis, Egypt 2014-2018. 2014. Available at: 
http://www.emro.who.int/images/stories/ egypt/VH_Plan_of_Action_FINAL_PRI

NT1.pdf. (Accessed 27 June 2018).

10. Lucinda K., Porter R, Ranciscus A. HCSP guides: A guide to: Treatment side effect management: Interferon based therapies. HCV Advocate. Version 6.5 January 2015. Available at: http://hcvadvocate.org/hepatitis/factsheet s_pdf/Treatment_Side_Effect_Guide.pdf . (Accessed 25 May 2018).

11. Gower E, Estes C, Blach S et al. Global epidemiology and genotype distribution of the hepatitis $\mathrm{C}$ virus infection. $\mathrm{J}$ Hepatol. 2014; 61(1):S45-57. [PMID: 25086286]. Available at: http://dx.doi.org/10.1016/j.jhep.2014.07. 027. (Accessed 20 June 2018).

12. Evon D, Simpson K, Esserman D et al. Barriers to accessing care in patients with chronic hepatitis $\mathrm{C}$ : the Coalition impact of depression. Aliment Pharmacol Ther. 2010; 32:1163-1173.

13. Parkes J, Roderick P, Bennett-Lloyd B et al. Variation in hepatitis $C$ services may

Egyptian Family Medicine Journal (EFMJ) http://efmj.journals.ekb.eg/ lead to inequity of health-care provision: a survey of the organization and delivery of services in the United Kingdom. BMC Public Health. 2006; 6:3.

14. Li Z, Zhang L, Wang J, Huang L et al. Hepatitis C infection, related services, and barriers to $\mathrm{HCV}$ treatment among drug users in methadone maintenance treatment (MMT) clinics in Shanghai, China. Harm Reduct J. 2017; 14:71. DOI 10.1186/s12954-017-0197-3.

15. Falade-Nwulia O, McAdams-Mahmoud A, Irvin $\mathrm{R}$ et al. Primary care providers' knowledge, attitude and practices related to hepatitis $\mathrm{C}$ screening and treatment in the Oral Direct Acting Antiviral Agents Era. J Community Med Health Educ. 2016; 6 (5): 481. [PMID: $28083156 \quad$ DOI: $10.4172 / 2161-$ 0711.1000481]

16. Myles A. The role of physicians' attitudes and the provision of hepatitis $\mathrm{C}$ virus treatment to people who inject drugs. Open Med J, 2016, 3, (Suppl 1: M6) 104-112.

DOI: 10.2174/187422030160301010. 
17. Kandeel A, Genedy M, El-Refai S et al. The prevalence of hepatitis $\mathrm{C}$ virus infection in Egypt 2015: implications for future policy on prevention and treatment. Liver Int 2017; 37(1): 45-53.
Available at: https://www.ncbi.nlm.nih.gov/pmc/articl es/PMC5145777/ (Accessed 25 December 2018). 


\section{Table (1): Physicians' Opinions regarding HCV Care}

\begin{tabular}{|l|c|c|}
\hline \multicolumn{1}{|c|}{ Respondents in agreement with the statement } & No. & \% \\
\hline - National treatment guidelines are available in my country & 60 & 87.0 \\
\hline $\begin{array}{l}\text { - Government and/or payers recognize national or international treatment } \\
\text { guidelines }\end{array}$ & 53 & 79.1 \\
\hline $\begin{array}{l}\text { - } \text { Treatment guidelines and policies are consistent among professional } \\
\text { societies, payers, and government }\end{array}$ & 52 & 75.4 \\
\hline - Healthcare providers have knowledge of screening and treatment & & \\
\hline guidelines & 47 & 69.1 \\
\hline - Patients have adequate access to HCV providers in their community. & 42 & 60.9 \\
\hline - The general public is aware of HCV & 31 & 45.6 \\
\hline - Most patients are aware that HCV is curable; & 21 & 30.4 \\
\hline - Patients understand the consequences of HCV if it is not treated & 18 & 26.9 \\
\hline
\end{tabular}


Table (2): Physicians' knowledge regarding HCV treatment indication, dose and contraindication

\begin{tabular}{|c|c|c|}
\hline $\begin{array}{c}\text { Statements of } \\
\text { Respondents with Right Answer } \\
\end{array}$ & No. & $\%$ \\
\hline - Addition of ribavirin to sofosbuvir improves the likelihood of SVR & 59 & 85.5 \\
\hline $\begin{array}{l}\text { - Maintaining an optimal dose of ribavirin with sofosbuvir is necessary to achieve an } \\
\text { SVR }\end{array}$ & 36 & 52.9 \\
\hline - Different viral genotypes require different treatment durations & 54 & 78.3 \\
\hline $\begin{array}{l}\text { - Treatment should be discontinued for patients who fail to achieve a 2-log decrease } \\
\text { in HCV RNA by treatment week } 12\end{array}$ & 27 & 39.1 \\
\hline $\begin{array}{l}\text { - Treatment should be discontinued for patients who have detectable HCV RNA at } \\
\text { treatment week } 4\end{array}$ & 6 & 8.7 \\
\hline $\begin{array}{l}\text { - Patients with stage } 1 \text { fibrosis have worse treatment outcomes than patients with } \\
\text { stage } 4 \text { fibrosis }\end{array}$ & 0 & 0.0 \\
\hline - level of HCV RNA has no correlation with the severity of liver disease & 36 & 52.2 \\
\hline - Maintenance therapy should be prescribed for treatment non-responders & 1 & 1.4 \\
\hline $\begin{array}{l}\text { - Sovaldi is given when Adult patients with genotype } 1,2,3 \text { or } 4 \text { chronic hepatitis } \mathrm{C} \\
\text { virus (HCV) infection without cirrhosis only }\end{array}$ & 3 & 4.3 \\
\hline $\begin{array}{l}\text { - Pediatric patients } 12 \text { years of age and older or weighing at least } 35 \mathrm{~kg} \text { with } \\
\text { genotype } 2 \text { or } 3 \text { chronic HCV infection without cirrhosis sovaldi is given in } \\
\text { combination with interferon }\end{array}$ & 6 & 8.8 \\
\hline $\begin{array}{l}\text { - Patients' genotype } 1 \text { or } 4 \text { infection without cirrhosis or with compensated cirrhosis; } \\
\text { sovaldi is given in combination with peginterferon-alfa and ribavirin }\end{array}$ & 10 & 14.5 \\
\hline $\begin{array}{l}\text { - Genotype } 2 \text { or } 3 \text { infection without cirrhosis or with compensated cirrhosis in } \\
\text { combination with ribavirin }\end{array}$ & 38 & 55.1 \\
\hline - Sofosbuvir is a $400 \mathrm{mg}$ pill taken once-a-day & 56 & 82.4 \\
\hline - Pegylated interferon (PEG) is injected under the skin once-a-day * & 5 & 7.2 \\
\hline $\begin{array}{l}\text { - Ribavirin (pill) taken twice daily. The dose of ribavirin is based on body weight } \\
(<75 \mathrm{~kg}=1000 \mathrm{mg} ; \geq 1000 \mathrm{~kg}=1200 \mathrm{mg})\end{array}$ & 52 & 75.4 \\
\hline $\begin{array}{l}\text { - Sovaldi plus PEG/RBV is also approved to treat HCV in people co-infected with } \\
\text { HIV }\end{array}$ & 26 & 38.8 \\
\hline $\begin{array}{l}\text { - The patients in the trial who were over } 65 \text { years don't have similar cure rates as } \\
\text { those less than } 65 \text { years. No drug dose reductions were required in this age group } \\
*\end{array}$ & 26 & 38.2 \\
\hline - Sovaldi dose adjustment for people with mild-to-moderate kidney impairment $*$ & 27 & 39.1 \\
\hline $\begin{array}{l}\text { - Sovaldi dose adjustments for people with liver impairment, but people with } \\
\text { decompensated cirrhosis were not studied in the clinical trials } *\end{array}$ & 21 & 30.9 \\
\hline - People with liver cancer pre-transplant cannot be treated with sofosbuvir/ribavirin * & 32 & 46.4 \\
\hline $\begin{array}{l}\text { - Women must have a negative pregnancy test prior to therapy and must use at least } 2 \\
\text { effective non-hormonal methods of birth control. A woman must have monthly } \\
\text { pregnancy tests }\end{array}$ & 53 & 76.8 \\
\hline $\begin{array}{l}\text { - Sovaldi should not be taken with certain medications such as HIV medications, } \\
\text { anti-mycobacterials and anticonvulsants }\end{array}$ & 59 & 85.5 \\
\hline
\end{tabular}

(*) Means wrong statement 
Table (3): Physicians' knowledge regarding HCV treatment adverse events

\begin{tabular}{|l|c|c|}
\hline \multicolumn{1}{|c|}{ Statement of Respondents with Right Answer } & No. & $\%$ \\
\hline $\begin{array}{l}\text { - The most common adverse events observed with Sovaldi in combination with } \\
\text { ribavirin were fatigue and headache }\end{array}$ & 55 & 79.7 \\
\hline $\begin{array}{l}\text { - } \text { The most common adverse events observed with SOVALDI in combination with } \\
\text { peginterferon alfa and ribavirin were fatigue, headache, nausea, insomnia and } \\
\text { anemia }\end{array}$ & 58 & 84.1 \\
\hline - Sovaldi don't cause Hepatitis B virus reactivation * & 20 & 29.0 \\
\hline - Sovaldi causes slow heart rate (bradycardia) when taken with amiodarone & 59 & 85.5 \\
\hline
\end{tabular}

(*) Means wrong statement 
Table (4): Physicians' response about patient related and government related barriers against HCV treatment

\begin{tabular}{|c|c|c|}
\hline Respondents in agreement with the statement & No. & $\%$ \\
\hline \multicolumn{3}{|l|}{ Patient-related barriers } \\
\hline - Medication expense & 57 & $85.1 \%$ \\
\hline - Laboratory expense & 57 & $85.1 \%$ \\
\hline - Patient declines liver biopsy & 40 & $58.8 \%$ \\
\hline - Inaccessibility of experienced providers & 35 & $51.5 \%$ \\
\hline - Fear of side-effects & 33 & $49.3 \%$ \\
\hline - Lack of proper storage for medications & 33 & $48.5 \%$ \\
\hline - $\quad$ Treatment duration & 30 & $44.8 \%$ \\
\hline - $\quad$ Preference for alternative therapy & 29 & $42.7 \%$ \\
\hline - Difficulty with administration & 22 & $32.4 \%$ \\
\hline - Desire to wait for newer therapies & 9 & $13.4 \%$ \\
\hline - Fear of stigma related to HCV & 8 & $12.1 \%$ \\
\hline - Low success rate of treatment & 1 & $1.5 \%$ \\
\hline - Mean Patient related barriers score \pm SD (Min - Max $)$ & \multicolumn{2}{|c|}{$65.0 \pm 26.6(10.0-110.0)$} \\
\hline \multicolumn{3}{|l|}{ - $\quad$ Patient related barriers score categories } \\
\hline$\circ$ Low score $(<50 \%$ of total score $)(<60)$ & 24 & $38.1 \%$ \\
\hline$\circ \quad$ High score $(\geq 50 \%$ of total score $)(\geq 60)$ & 39 & $61.9 \%$ \\
\hline \multicolumn{3}{|l|}{ Government-related barriers } \\
\hline - Lack of promotion for $\mathrm{HCV}$ treatment & 40 & $58.8 \%$ \\
\hline - Insufficient funds allocated to HCV & 33 & $48.5 \%$ \\
\hline - Government restricts treatment & 21 & $30.9 \%$ \\
\hline - Mean Government related barriers score \pm SD $($ Min - Max $)$ & \multicolumn{2}{|c|}{$16.9 \pm 10.5(.0-30.0)$} \\
\hline \multicolumn{3}{|l|}{ - Government related barriers score categories } \\
\hline$\circ$ Low score $(<50 \%$ of total score $)(<15)$ & 23 & $33.8 \%$ \\
\hline$\circ \quad$ High score $(\geq 50 \%$ of total score) $(\geq 15)$ & 45 & $66.2 \%$ \\
\hline
\end{tabular}


Table (5): Physicians' response about patient related and government related barriers against HCV treatment

\begin{tabular}{|c|c|c|}
\hline Respondents in agreement with the statement & No. & $\%$ \\
\hline \multicolumn{3}{|c|}{ Provider-related barriers } \\
\hline Lack of referral to HCV providers by other physicians & 31 & $47.0 \%$ \\
\hline Insufficient reimbursement for physicians & 25 & $38.5 \%$ \\
\hline Lack of office infrastructure to treat patients & 23 & $34.8 \%$ \\
\hline Limited access to medications or labs & 4 & $6.1 \%$ \\
\hline Unable to obtain necessary labs for treatment & 2 & $3.0 \%$ \\
\hline Insufficient training for $\mathrm{HCV}$ management & 2 & $3.0 \%$ \\
\hline Treatment limited to government-mandated centers & 1 & $1.5 \%$ \\
\hline Mean Provider related barriers score \pm SD $($ Min - Max $)$ & \multicolumn{2}{|c|}{$24.3 \pm 12.5(5.0-45.0)$} \\
\hline \multicolumn{3}{|l|}{ Provider related barriers score categories } \\
\hline Low score $(<50 \%$ of total score $)(<35)$ & 50 & $76.9 \%$ \\
\hline High score $(\geq 50 \%$ of total score $)(\geq 35)$ & 15 & $23.1 \%$ \\
\hline \multicolumn{3}{|c|}{ Payer-related barriers } \\
\hline Insurer does not cover serum markers of fibrosis & 56 & $84.8 \%$ \\
\hline Insurance plans will not cover RNA/genotyping & 50 & $75.7 \%$ \\
\hline Insurance plans limit which physicians treat $\mathrm{HCV}$ & 46 & $68.7 \%$ \\
\hline Excessive paperwork requirements & 40 & $59.7 \%$ \\
\hline Insurance plans do not cover medications for side-effects & 36 & $54.5 \%$ \\
\hline Restricted insurance coverage for patients with $\mathrm{HCV}$ & 12 & $17.9 \%$ \\
\hline High out-of-pocket expense for patients & 11 & $16.4 \%$ \\
\hline Liver biopsy required for treatment & 1 & $1.5 \%$ \\
\hline Insurance plan does not cover treatment & 1 & $1.5 \%$ \\
\hline Mean Payer related barriers score \pm SD $($ Min - Max $)$ & \multicolumn{2}{|c|}{$53.1 \pm 10.4(10.0-65.0)$} \\
\hline \multicolumn{3}{|l|}{ Payer related barriers score categories } \\
\hline Low score $(<50 \%$ of total score $)(<45)$ & 8 & $12.1 \%$ \\
\hline High score $(\geq 50 \%$ of total score $)(\geq 45)$ & 58 & $87.9 \%$ \\
\hline
\end{tabular}


Table (6): Physicians' response about patient related and government related barriers against HCV treatment

\begin{tabular}{|c|c|c|c|c|c|}
\hline \multicolumn{2}{|c|}{ Variables } & $\begin{array}{c}\text { Patients' } \\
\text { Barriers score }\end{array}$ & $\begin{array}{c}\text { Governmental } \\
\text { barriers score }\end{array}$ & $\begin{array}{c}\text { Providers' } \\
\text { barriers } \\
\text { score }\end{array}$ & $\begin{array}{c}\text { Payers' } \\
\text { barriers } \\
\text { score }\end{array}$ \\
\hline $\begin{array}{c}\text { Total } \\
\text { knowledge score }\end{array}$ & $\begin{array}{c}\text { Pearson } \\
\text { Correlation }\end{array}$ & $-\mathbf{0 . 3 9 6 * *}$ & $\mathbf{0 . 1 9 9}$ & $\mathbf{0 . 3 3 8 * *}$ & $\mathbf{0 . 1 4 9}$ \\
\cline { 2 - 6 } & $\mathbf{P}$ & $\mathbf{0 . 0 0 2}$ & $\mathbf{0 . 1 1 7}$ & $\mathbf{0 . 0 0 7}$ & $\mathbf{0 . 2 4 5}$ \\
\hline
\end{tabular}




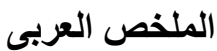

\section{معرفة الأطباء والعوائق المدركة اتجاه الألتهاب الكبدي الوبائي سي في مستثفى جامعة عين شمس}

منار محمح اللبان - ميرفت حسن راضى - هبه الله حمح صلاح جبل - نيرة سامى مصطفى

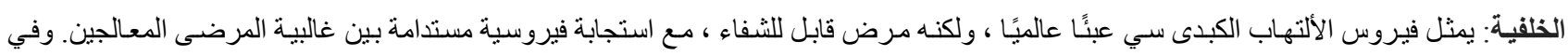

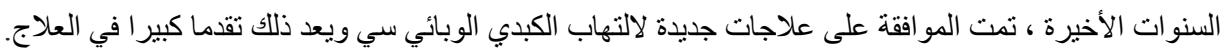

الهذف: أجريت هذه الدر اسة لتقييم المعرفة والآراء والعو ائق المتصورة ضد نظام العلاج القائم علي مضاد للفيروسات المباثر (DAAs) بين عينة من مقدمي العلاج من فيروس الالتهاب الكبدى الوبائي سي.

المشاركون وطرق البحث: أجريت در اسة مستعرضـة لمقدمي العلاج من فيروس الألتهاب الكبدي سي في الدمرداش بمستشفى عين شمس الجامعي. و قد أجاب ما مجمو عه 69 طبيبا على استبيان يملأ ذاتيا حول معرفتهم ، ووجهات النظر حول الخدمات المقدمة وتصور هم للحو اجز ضد العلاج. النتائج: معظم آراء الأطباء تتفق مع الوضع الراهن للرعاية بفيروس التهاب الكبد (سي) حيث توجد مبادئ توجيهية ، كما أن المرضى يستطيعوا الوصول

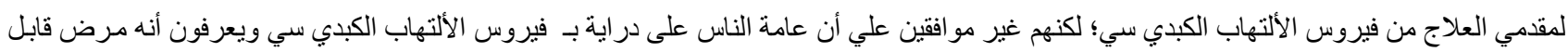

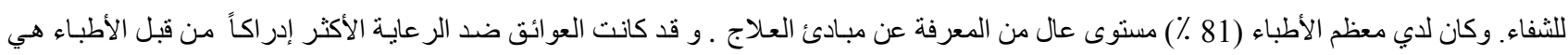

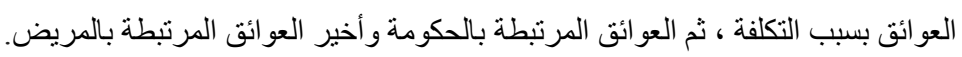

الخلاصة و التوصيات: تسلط الدراسة الضوء على العو ائق الأكثر إدر اكًا التي قد تعوق المعالجة الفورية واللازمة لعدوى فيروس الالتهاب الكبدي الوبائي التي

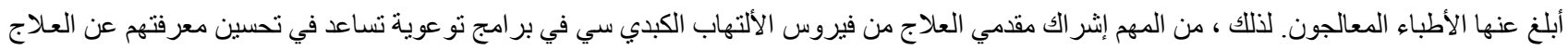

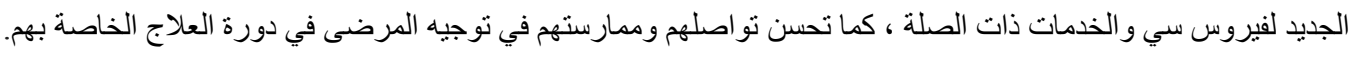

